\title{
Investigation of Flexible Pavement Failure along Ede - Akoda Road, Osun State, Southwestern Nigeria \\ ${ }^{1}$ Tijani, M. A. and ${ }^{2}$ Olawale, S. O. A. \\ ${ }^{1,2}$ Department of Civil Engineering, Osun State University, Osogbo, Osun State, Nigeria. \\ Corresponding E-mail: murtadha.tijani@ uniosun.edu.ng
}

\section{Abstract}

DOI: 10.36108/laujoces/0202/40(0110)

Ede to Akoda is a trunk B-road built over 30 years ago. It has been in despicable condition leading to fatal accidents and loss of life and properties that impacted negatively on the community. This study investigated the flexible pavement failure along the road in order to ascertain the possible causes of its failure. The methodology adopted covered reconnaissance survey, assessment of the physical condition of the road and soil investigation of subgrade. The result of reconnaissance survey revealed that the surface wearing course has degraded extensively. The physical inspections showed that considerable segment of the drainage facilities has collapsed or totally blocked allowing extensive ponding of rain water on the road surface. The pot holes were deep and widespread in most places and the road is near total collapse. The result of soil investigation revealed that natural moisture content, specific gravity, liquid limit, plastic limit, plastic index, maximum dry density and optimum moisture content were within the specifications of the Federal Ministry of Works and Housing limits (FMWH). However, the California bearing ratio values were less than minimum $10 \%$ stated in the specifications, this suggests the nature of subgrade soil as a possible cause of failure of road pavements along Ede-Akoda Road, Nigeria. It is recommended that further research be conducted on other structures of the flexible pavement to better ascertain the causes of the studied road failure.

Keywords: Ede, Flexible pavement failure, Road network, Subgrade, wearing course.

\section{Introduction}

Road Network is an essential constituent of infrastructural development that is required for the economic development of a nation. In Nigeria, apart from serious deficit of road network, the few existing ones are either completely neglected to deteriorate to the state of disrepair or poorly maintained. The wearing course is the area the deterioration of the road first manifests. This may due to the poor foundation, subgrade structure underneath, or mere tear and wear of the wearing course (Akinleye and Tijani, 2017). Paved road can be flexible or rigid construction. Whatever the choice, with good engineering, the road should out live its design life and serves the community well (Shere, Worku and Keno, 2018). The principal function is to receive load from the traffic and conveys it through its layer to the subgrade (Gupta, 2014). Ogundipe (2008) stated that a pavement is said to be defective when it can no longer perform this function during its design life. Tijani, Akinleye and Jaiyeoba (2017) and Arinze (2006) noted that most roads in Nigerian urban and rural areas today are characterized by potholes, cracks, ruts, depression and so on.

According to Atumu (2007), some of the causes of these conditions of the roads in Nigeria were use of low quality materials in construction, poor design and construction, poor maintenance of built roads, poor supervision of highway construction works, plying of heavy traffic not meant for the road on the road. Other causes may be attributable to sudden increase in traffic loading especially on new roads where the design is based on lesser traffic (Rather and Lateef, 2016) and provision of poor clayey sub-grade which results in corrugation at the surface and increase in unevenness (Gupta and Sharad, 2004). The recommendations to remedy the situation as stated by Arinze (2006) include avoiding unnecessary congestion of the roads with traffic especially heavy traffic that were not meant for the roads, use of appropriate design of the roads, use of suitable construction materials in the construction of the roads, prompt maintenance of the roads, use of qualified engineering personnel in road construction, application of appropriate tests to the soil in road construction and the application of sanction for highway failures. 
Many authors have worked on investigation of flexible pavement failure. Research carried out by Shere $e t$ al. (2018), Rather and Lateef (2016), Adegoke and Agada (1980), Mesida (1981) and Ajayi (1987) showed that road failures can arise from inadequate knowledge of the geotechnical characteristics and behaviour of residual soils on which the roads are built and non-recognition of the influence of geology and geomorphology during the design and construction phases. Thus, the treatment of troublesome materials like clays are not considered by the construction engineers which may be problematic. This was also supported by the works of Gupta (2003) and Ajani (2006). Gupta (2014), Momoh et al (2008) and Adiat et al (2009) in their study of failed highway pavements using geophysical methods, found that some geological factors influence road failure such as the near surface geologic sequence, existence of geological structures like fractures and faults, presence of laterites, existence of ancient stream channels, and shear zones.

According to Adrox and Woods (2002), the collapse of concealed subsurface geological structures and other zones of weakness controlled by regional fractures and joint systems along with silica leaching which has led to rock deficiency are known to contribute to failures of highways and rail tracks. The geomorphologic factors are related to topography and surface/subsurface drainage system but the scale of deterioration of road network in Nigeria is astronomical and such phenomenon could not be totally and globally responsible. Although, according to the work of Onuoha and Onwuka (2014), the present condition of most of the roads in the Precambrian basement complex of south western Nigeria and the sedimentary terrain of the southeast and the entire Niger-Delta region has stimulated the interest of various stakeholders in the usage and maintenance of our road ways. Rehabilitating these roadways have become a financial burden on the Federal, State, and Local Governments. The contribution of Ede - Akoda Road to the economy of Edeland cannot be over emphasised. However, literature is sparse on its flexible pavement failure investigation. Thus, the need for this research.

\section{Material and Methods}

This research work investigated flexible pavement in the study area through visual assessment on the flexible surface condition and drainage assessment. Sampling and laboratory tests were carried out based on the nature of the failure of Ede - Akoda road as shown in Figure 1.

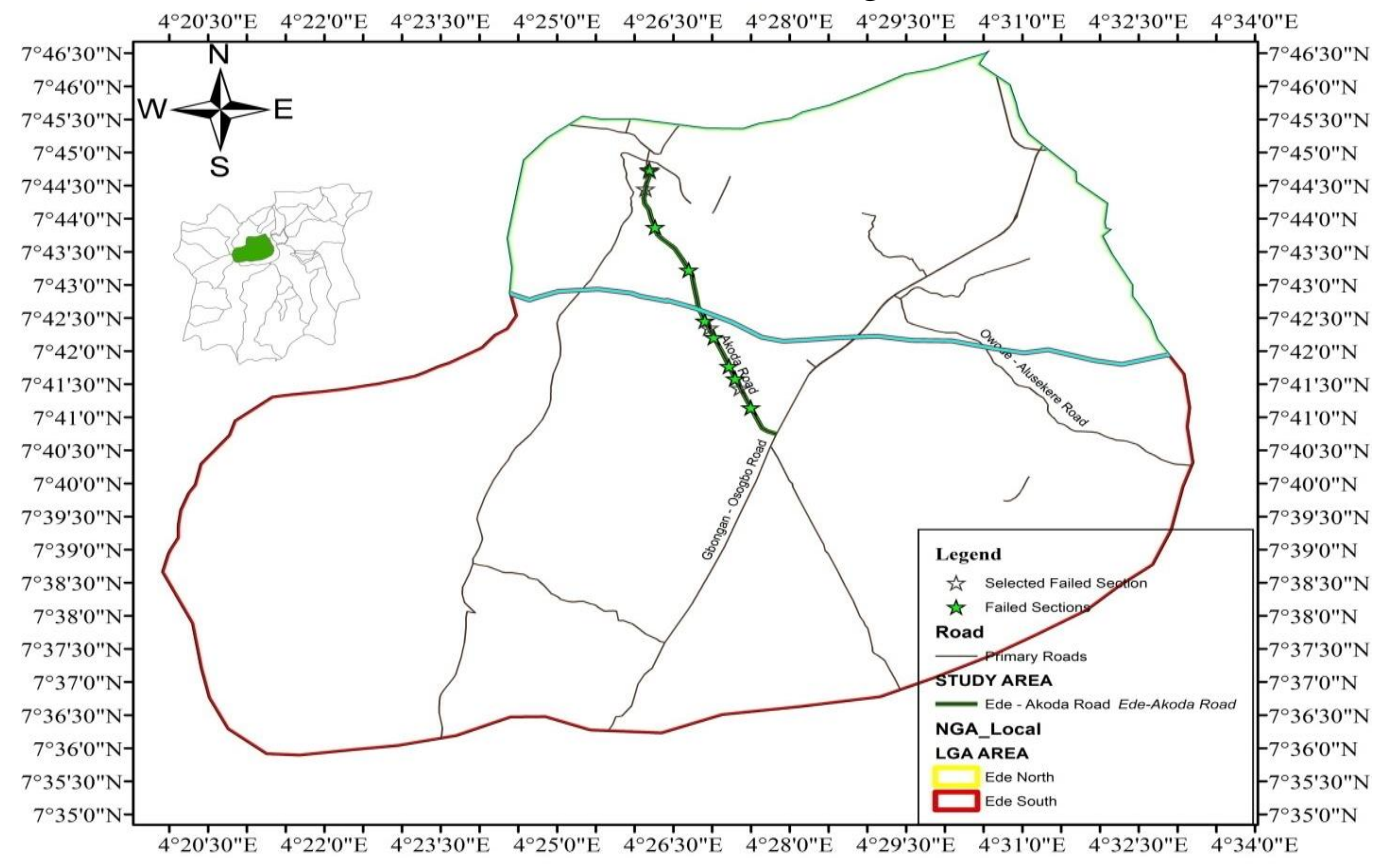

Figure 1: Map showing Ede - Akoda Road in Osun State (Google Map)

The approach adopted for this study was in two parts, physical survey and subgrade soil analysis in the laboratory. The physical inspection involved the reconnaissance survey and mapping of the damaged locations where samples were taken for analysis. The drainage conditions along the length of the road were 
Volume 4, Issue 1; March 2020

assessed. Pavement condition survey was rated using the Pavement Condition index (PCI) which ranges from 0 for a failed road to 100 for a road with no visible distress. The PCI was calculated from the results of a visual condition survey in which the severities and quantities of distress types such as potholes, cracking and rutting were identified and measured.

For the laboratory analysis of the subgrade materials, five locations of worst damage (Table 1) were selected and samples were collected. These were used for the following tests:

a) Natural moisture content

b) Particle size analysis

c) Atterberg limit

d) Specific gravity

e) Compaction test (Maximum dry density and Optimum moisture content)

f) California bearing ratio $(\mathrm{CBR})$

Table 1: Location of dug Pits

\begin{tabular}{lll}
\hline Sample & Location & Coordinates \\
\hline Loc1 & Opposite Total Filling Station & $7.74755819 \mathrm{~N}$ \\
& & $4.43574070 \mathrm{E}$ \\
Loc2 & Opposite Atapara market & $7.74077569 \mathrm{~N}$ \\
& & $4.43583730 \mathrm{E}$ \\
Loc3 & Opposite Oando Oil, Agip & $7.72511049 \mathrm{~N}$ \\
& & $4.44172199 \mathrm{E}$ \\
Loc4 & Opposite 7days Adventist & $7.71534199 \mathrm{~N}$ \\
& & $4.44504560 \mathrm{E}$ \\
Loc5 & Ededimeji junction & $7.69736580 \mathrm{~N}$ \\
& & $4.45351240 \mathrm{E}$ \\
\hline
\end{tabular}

\section{Water content of soil}

The water content of the soil is the ratio of weight of water present in the soil mass to the weight of soil solid. It is also known as moisture content. The moisture content of the soil was determined in accordance with BS 1377 (1990) Part 2. Empty containers was cleaned and weighed to the nearest 0.01g as $\mathbf{M}_{1}$. The sample as freshly collected was crumbled and placed loosely in the containers and the containers with the samples were weighed together to the nearest $0.01 \mathrm{~g}$ as $\mathrm{M}_{2}$. The containers were then placed in the oven and dried at $100^{\circ} \mathrm{C}-110^{\circ} \mathrm{C}$ for 24 hours. The containers and the dried samples were then removed and weighed to the nearest $0.01 \mathrm{~g}$ as $\mathrm{M}_{3}$. The water content will be calculated using eqn. (1).

$$
w=\frac{M_{2}-M_{3}}{M_{3}-M_{1}} \times 100
$$

Where $\mathrm{w}$ is the water content in percentage.

\section{Specific gravity of soil}

Specific gravity is the number of times the soil solids are heavier than equal volume of water. The density bottle and the stopper were weighed to the nearest $0.001 \mathrm{~g}$ as $\mathrm{M}_{1}$. The air dried soil was transferred into the density bottle, and the bottle, content and the cover were weighed as $\mathbf{M}_{2}$. Water was then added just enough to cover the soil and the solution was stirred gently to remove any air bubble. The bottle was then completely filled up and covered. The covered bottle was wiped dry and the whole weighed to the nearest $0.001 \mathrm{~g}$ as $\mathrm{M}_{3}$. The bottle was subsequently emptied and filled completely with water, wiped dry and weighed to the nearest $0.001 \mathrm{~g}$ as $\mathrm{M}_{4}$. Specific gravity is always measured in room temperature. The specific gravity was calculated using eqn. (2).

$$
G_{s}=\frac{M_{2}-M_{1}}{\left(M_{4}-M_{1}\right)-\left(M_{3}-M_{1}\right)}
$$


Investigation of Flexible Pavement Failure along Ede - Akoda Road, Osun State, Southwestern Nigeria

Where $\mathrm{G}_{\mathrm{s}}$ is the specific gravity.

\section{Atterberg limit}

This was used in determination of the liquid limit, plastic limit and plasticity index for the soil. It was done in accordance with Test 1(A) BS 1377 (1990). This test is also known as plasticity tests and determined as follows.

\section{Liquid limit}

This was done using Casangrande apparatus. This is done with soil of at least $200 \mathrm{~g}$ that passed through BS sieve number $40(425 \mu \mathrm{m})$, the soil was placed on a glass plate then mixed with water to form a homogeneous paste. A portion of the soil-water mixture was then placed in the cup of the Casangrande apparatus, levelled off parallel to the base and a groove was then cut at the centre of the soil paste, with standard grooving tool. The cup was lifted up and drops by turning the crank until the two parts of the soil come into contact at the bottom of the groove. The number of blow at which that occurs was recorded and a little quantity of the soil was taken and its moisture content was determined as section 3.3.1. The values of the moisture content determined and the corresponding number of blows was plotted on a semilogarithmic graph and the liquid limit was determined as the moisture content corresponding to 25 blows.

\section{Plastic limit}

Some portion of the soil used for the liquid limit test was retained for the determination of plastic limit. Ball of the soil was moulded between the fingers and rolled between the palms of the hand until it dried sufficiently. The sample was divided into approximately four equal parts. Each of the parts was rolled into a thread between the first finger and the thumb. The thread was then rolled between the tip of the fingers of one hand and the glass. This was continued until the diameter of the thread is reduced to about $3 \mathrm{~mm}$ in five to ten forward and backward movements of the hand. The crumbled soil was then put in the moisture container and the moisture content determined.

\section{Plasticity index}

The plasticity index of the soil mix is the difference between the liquid limits of the soil and their plastic limits.

Where:PI = plasticity index

$$
P I=L L-P L
$$

$\mathrm{LL}=$ liquid limit

$\mathrm{PL}=$ plastic limit.

\section{Particle size distribution}

The particle size analysis test was carried out in accordance with BS 1377 (1990) Part 2. Wet sieving was conducted by measuring $2000 \mathrm{~g}$ of the soil sample and soaking it for 24 hours. The sample was then washed through BS sieve No 200. The particles retained were dried in the oven for 24 hours and a dry sieving was then carried out on the dried sample to obtain the particle size distribution. The results from sieve analysis of the soil when plotted on a semi-log graph with particle diameter or the sieve size as the abscissa with logarithmic axis and the percentage passing as the ordinate gives a clear idea about the particle size distribution.

\section{Compaction}

This experiment gives a clear relationship between the dry density of the soil and the moisture content of the soil. The compactive energy level used is the West African Standard (WAS). It consists of energy level derived from a $4.5 \mathrm{~kg}$ rammer falling through $450 \mathrm{~mm}$ height onto five layers using 10 uniformly distributed blows each. It is done in a $1000 \mathrm{~cm}^{3}$ mould (Ola, 1983). Air dried soil samples passing through BS sieve with $4.76 \mathrm{~mm}$ aperture was used. The experimental setup consists of cylindrical metal mould, detachable 
Volume 4, Issue 1; March 2020

base plate, collar ( $5 \mathrm{~cm}$ effective height) and rammer $(4.5 \mathrm{~kg})$. Compaction process helps in increasing the bulk density by driving out the air from the voids. The theory used in the experiment is that for any compactive effort, the dry density depends upon the moisture content in the soil. After compaction, the collar was removed and the compacted sample leveled off at the top of the mould with a straight edge. The weight of mould used during the process was taken initially to the nearest $1 \mathrm{~g}$ as $\mathrm{M}_{1}$. The mould containing the leveled sample was then weighed to the nearest $1 \mathrm{~g}$ as $\mathbf{M}_{2}$. Afterwards, samples were taken from the compacted soil and a minimum of three sets of sample will be taken for moisture content determination. The bulk density in $\mathrm{g} / \mathrm{cm}^{3}\left(\mathrm{Mg} / \mathrm{m}^{3}\right)$ was later calculated for each compacted soil using:

$$
\rho=\frac{M_{2}-M_{1}}{V}
$$

Where: $\rho=$ bulk density of the soil $\left(\mathrm{g} / \mathrm{cm}^{3}\right)$

$\mathrm{M}_{1}=$ mass of the mould $(\mathrm{g})$

$\mathrm{M}_{2}=$ mass of the mould + compacted soil $(\mathrm{g})$

$\mathrm{V}=$ volume of the mould $\left(\mathrm{cm}^{3}\right)$.

The dry density of the soil was also calculated using:

$$
\rho_{d}=\frac{\rho}{(1+w)}
$$

Where: $\rho_{d}=$ dry density of the soil $\left(\mathrm{g} / \mathrm{cm}^{3}\right)$

$\rho=$ bulk density of the soil $\left(\mathrm{g} / \mathrm{cm}^{3}\right)$

$\mathrm{w}=$ moisture content

\section{California bearing ratio (CBR)}

The test was a penetration test for evaluation of the mechanical strength of road sub grades and sub base. The test is performed by measuring the pressure required to penetrate a soil sample with a plunger of standard area. The measured pressure is then divided by the pressure required to achieve an equal penetration on a standard crushed rock material. The CBR test was performed in accordance with Nigeria general specification (1992), which stimulates that specimen should be cured for six days, un-soaked and immersed in water for one day before testing.

$$
C B R=\frac{P}{P S} X 100 \%
$$

Where:

$\mathrm{P}=$ plunger-load in $\mathrm{N} / \mathrm{mm}^{2}$ for tested soil (Penetration load).

$\mathrm{P}_{\mathrm{S}}=$ plunger-load in $\mathrm{N} / \mathrm{mm}^{2}$ for standard soil (Standard load).

Standard load at $2.5 \mathrm{~mm}$ penetration is $13.24 \mathrm{kN}$ and at $5.0 \mathrm{~mm}$ penetration is $19.96 \mathrm{kN}$.

\section{Results and Discussion}

The results of field survey which include reconnaissance survey of pavement condition and soil testing are presented in this section. Laboratory soil test results include Natural Moisture Content, Particle Size Analysis, Atterberg Limits, Specific Gravity, Compaction tests, California Bearing Ratio are presented in tables and figures.

\section{Natural Moisture Content and Specific Gravity}

Natural moisture content is one of the most common soil parameter. Low moisture content indicates the soil is a dry one, while high amount of moisture content indicates a wet soil. From Table 2, soils in the study area have moisture content ranging from 7.4 to $10.4 \%$ which were within 5 to $15 \%$ specified in 
Investigation of Flexible Pavement Failure along Ede - Akoda Road, Osun State, Southwestern Nigeria

FMWH (1992). Samples with high moisture content are not suitable for road construction while those with low moisture content are most suitable for road construction. The specific gravity of the samples Loc1 to Loc5 were 2.21, 2.15, 2.65, 2.06 and 2.29 respectively. This is a measure of the weight of the aggregate to the weight of an equal volume of water.

Table 2: Summary of the Natural Moisture Content and Specific Gravity

\begin{tabular}{ccc}
\hline Samples & Natural Moisture Content & Specific Gravity \\
\hline Loc1 & 9.1 & 2.21 \\
Loc2 & 8.8 & 2.15 \\
Loc 3 & 7.9 & 2.65 \\
Loc4 & 10.4 & 2.06 \\
Loc5 & 7.4 & 2.29 \\
\hline
\end{tabular}

\section{Atterberg Limit}

From the results of atterberg limit in Table 3, the liquid limits values ranges from 26.00 to $48.63 \%$, the plastic limit is of order 14.98 to $36.48 \%$ while the plasticity index varied from 11.02 to $13.09 \%$. The liquid limits and plastic limit were all below 50 and 30\% respectively except for Loc 2 that had plastic limit of $36.48 \%$. They are within the acceptable requirements for soil sample that can be used as subgrade or fill during construction of highway in Nigeria (FMWH, 1992). These results indicate that the samples contain less fine particles such as clay and they have less affinity for water and low compressibility. Therefore, the failures may not be due to infiltration of water into the subgrade layer. The failure may therefore be due to some other factors.

Table 3: Summary of the Atterberg Limit

\begin{tabular}{cccc}
\hline Samples & Liquid Limit (\%) & Plastic Limit (\%) & Plasticity Index (\%) \\
\hline Loc1 & 39.31 & 26.22 & 13.09 \\
Loc2 & 48.63 & 36.48 & 12.15 \\
Loc3 & 26.00 & 14.98 & 11.02 \\
Loc4 & 40.02 & 27.92 & 12.10 \\
Loc5 & 29.65 & 19.42 & 10.23 \\
\hline
\end{tabular}

\section{Particle Size Distribution}

It is evident from the results presented that the subgrade soil is slightly plastic with moderate dry strength and of slight strength and the potential for expansion is medium. From AASHTO (1990) soil classification, it is evident that the subgrade soil of the road is between class A4 and A6. However, the particle size distribution (Figure 2) indicates a class A2 to A4 soil. This may be attributed to the mix of sand with clay that can result to poor compaction of the subgrade layer of the pavement. The amount of materials finer than No $200(0.075 \mathrm{~mm})$ BS test sieve ranges from minimum 27.10 for Loc 2 to $44.05 \%$ for Loc 3 . The percentage passing BS sieve No. 200 is less than 35\% except samples Loc 2 and Loc 5. These results (except samples Loc 2 and Loc 5) are within the requirements of FMW specification of materials used for road construction in terms of particles size. In addition, since the soil samples contain less fine particles, in the event of rise in water table around the area, the samples may not be adversely susceptible to swelling. Also, the smaller particles will fill the space between the large particles, thereby giving a dense mass of interlocking particles with high shear strength and low compressibility. 
Volume 4, Issue 1; March 2020

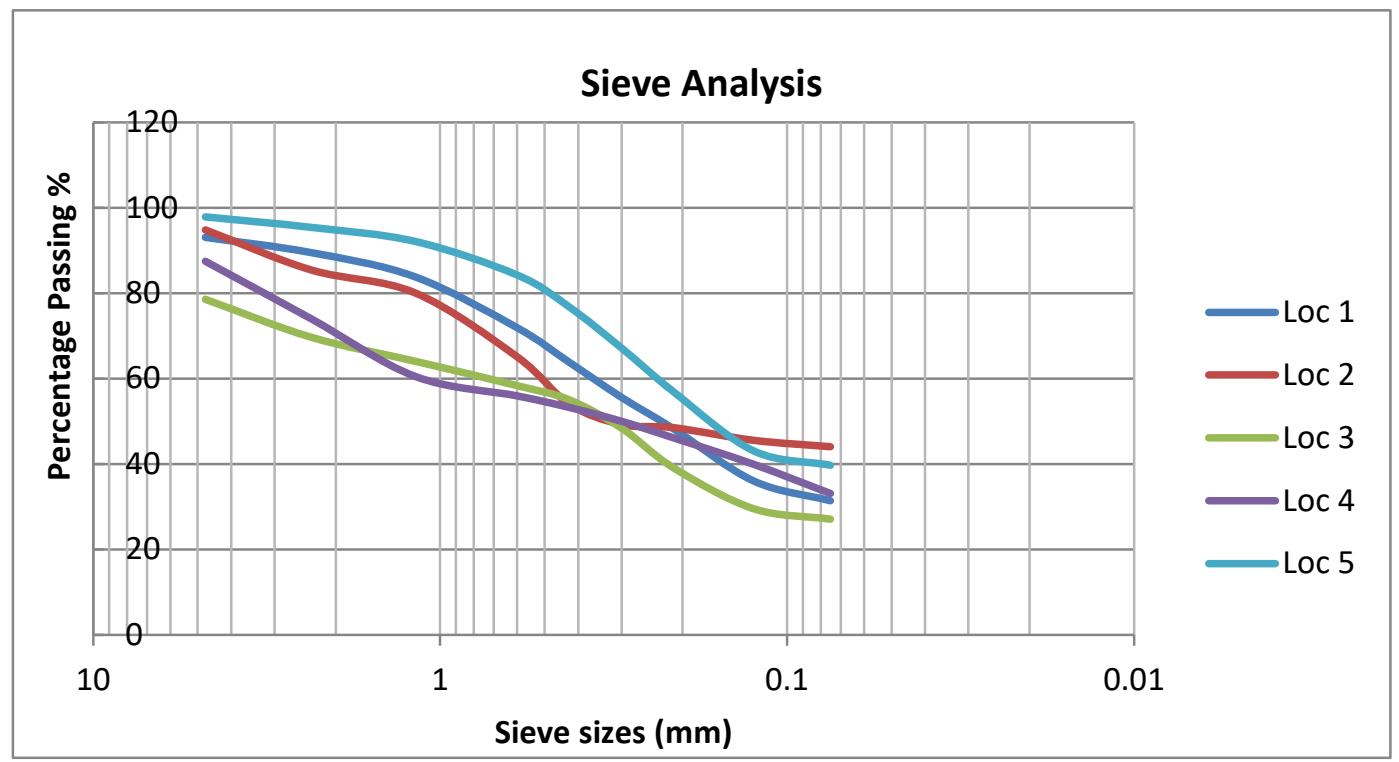

Figure 2: Particle Size Distribution Curve for soil sample at all locations

\section{Compaction}

The compaction data obtained from the laboratory test provides information on the performance of the soils under mechanical remoulding, as envisaged during earthworks and road construction. The maximum dry density of the samples ranged between $1.38 \mathrm{~g} / \mathrm{m}^{3}$ and $1.8 \mathrm{~g} / \mathrm{m}^{3}$ and optimum moisture content ranges between 13.14 and $16.50 \%$ (Table 5). These values are within the range of results obtained for soils within some parts of Southwest Nigeria (Bello et al., 2007; Agbede and Osuolale, 2005)

Table 5: Summary of MDD and OMC value

\begin{tabular}{lll}
\hline Samples & MDD $\left(\mathbf{g} / \mathbf{c m}^{\mathbf{3}}\right)$ & OMC $(\boldsymbol{\%})$ \\
\hline Loc1 & 1.58 & 15.12 \\
Loc2 & 1.56 & 13.14 \\
Loc3 & 1.42 & 14.45 \\
Loc4 & 1.38 & 16.50 \\
Loc5 & 1.44 & 13.28 \\
\hline
\end{tabular}

\section{California Bearing Ratio}

The California bearing ratio value (Table 6) for the samples were 8.3, 7.2, 9.3, 7.5 and 4.1\% for Loc1, Loc2, Loc3, Loc4 and Loc5 respectively. The Highway Design Manual, Federal Ministry of Works and Housing specification of soil characteristics for flexible pavement design specifies CBR value $10 \%$ minimum (soaked) for subgrade soil. Hence, the soil samples are not generally suitable for subgrade material and this may be the cause of the pavement failure of the study area.

Table 6: Summary of the California Bearing Ratio Value

\begin{tabular}{lc}
\hline Samples & Soaked CBR Value $(\boldsymbol{\%})$ \\
\hline Loc1 & 8.3 \\
Loc2 & 7.2 \\
Loc3 & 9.3 \\
Loc4 & 7.5 \\
Loc5 & 4.1 \\
\hline
\end{tabular}


Investigation of Flexible Pavement Failure along Ede - Akoda Road, Osun State, Southwestern Nigeria

\section{Conclusion}

A practical approach has been presented for the investigation of flexible pavement failure along Ede Akoda Road in Osun State in order to ascertain the possible causes of its failure. The result of reconnaissance survey revealed that the wearing course has degraded extensively and considerable segment of the drainage facilities has collapsed and blocked allowing extensive ponding of rain water on the road surface. The pot holes were deep and extensive in most places and the road is near total collapse. The result of soil investigation were within the specifications of the Federal Ministry of Works and Housing limits and some other researchers. However, the California bearing ratio values were less than minimum $10 \%$ stated in the specifications, suggesting that the nature of subgrade soil is a possible cause of failure of road pavements along Ede-Akoda Road, Nigeria. It is concluded that the poor drainage condition create the major causes of Ede-Akoda road segment failure. Further research is recommended to be conducted on other structures of the flexible pavement to better ascertain the causes of the studied road failure.

\section{References}

AASHTO (1990). Recommended Practice for the Classification of Soils and Soil-Aggregate Mixtures for Highway Construction Purposes. M 145-87. American Association of State Highway and Transportation Officials, 444 North Capitol Street, N.W., Suite 225, Washington D.C., 20001, AASHTO Specifications Part I.

Adegoke, W. C. and Agada, O. A. (1980). Geotechnical Characteristics of Some Residual Soils and their Implications on Road Design in Nigeria. Technical Lecture. Lagos, Nigeria. 1 - 16.

Adiat, K. A. N., Adelusi, A. O. and Ayuk, M. A. (2009). Relevance of Geophysics in Road Failures Investigation in a Typical Basement Complex of South Western Nigeria. Pacific Journal of Science and Technology. 5(1): 528-539.

Adrox, J. W. and Woods, W. R. (2002). A General Characterization of Pavement System Failures with Emphasis on a Method for Selecting Repair Process. Journal of Construction Education, 7(1), 58 - 62.

Agbede, O. A. and Osuolale, O. M. (2005). Geotechnical Properties of Subgrade Soil in Orire Local Government Area. Science focus, 10(2):137 - 141.

Ajani, A. R. (2006). Causes of Premature Failures on Nigeria Highways: A Training Course in Tunisia. Unpublished.

Ajayi, L. A. (1987). Thought on Road Failures in Nigeria. The Nigerian Engineer. 22 (1): 10 - 17.

Akinleye M. T. and Tijani M. A. (2017). Assessment of Quality of Asphalt Concrete used in Road Construction in South West Nigeria. Nigerian Journal of Technological Development, 14(2): 51 - 54.

Arinze E. E. (2006). Highway Maintenance in Nigeria: A Way Forward. Unpublished B.Eng. project submitted of Civil Engineering Department. Nnamdi Azikiwe University Awka.

Atume, F. T. (2007). Failure of Roads in Nigeria; Causes, Effects and Remedies. Proceeding: Annual Branch Public Lecture Series; the Nigerian Society of Engineers, Minna, Niger State, Nigeria, 7, 1314.

Bello, A. A., Ige, J. A. and Tajudeen, S. (2007). Geotechnical Characterization of Lateritic Soils in parts of Ejigbo Local Government Area, Southwestern Nigeria. LAUTECH Journal of Engineering and Technology, 4(2): 34-38.

British standard 1377 (1990). Method of Test for Soils for Civil Engineering Purposes, British Standard Institute London.

Federal Ministry of Works and Housing (FMWH), (1992). Highway Road Maintenance Manual, part II. Gupta, A. (2014). Comparative Structural Analysis of Flexible Pavements Using Finite Element Method. The International Journal of Pavement Engineering and Asphalt Technology, 15: 11-19.

Gupta, A. K. and Sharad, S. A. (2004). Pavement Deterioration and its Causes, IOSR Joural of Mechanical and Civil Engineering (IOSR-JMCE) 09-15.

Gupta, B. L. and Gupta, A. (2003). Roads, Railways, Bridges, Tunnel and Habour Dock Engineering;Standard. Publishers Distributors, Nai Sarak, Delhi. 5th Edition. 
Volume 4, Issue 1; March 2020

Mesida, E. A. (1981). Laterites on the Highways - Understanding Soil Behaviour. West African Technical Review. pp.112-118.

Momoh, L. O., Akintorinwa, O. and Olorunfemi, M. O. (2008). Geophysical Investigation of Highway Failure - A Case Study from the Basement Complex Terrain of Southwestern Nigeria. Journal of Applied Sciences Research, 4(6): 637-648.

Ola, S. A. (1983). Geotechnical Properties of an Attapulgite Clay Shale in Northwestern Nigeria. Engineering Geology. 19: 1-13.

Onuoha, D. C. and Onwuka, S. U. (2014). The Place of Soil Geotechnical Characteristics in Road Failure A Study of the Onitsha-Enugu Expressway, Southeastern Nigeria. Journal of Civil and Environmental Research. IISTE, USA. 6(1): 55-67.

Rather, I. A. and Lateef, E. (2016). Road Pavement Failure of Flexible Pavement from Sanat-Nagar to Pantha-Chowk. International Journal of Advanced Research in Education and Technology, 3(3): 135137.

Shere, T. K., Worku, A. and Keno, A. (2018). Laboratory Investigations on the Causes of Road Failures Constructed Along Asendabo to Deneba Road Section. International Journal of Engineering Research and Technology, 7(12): 127-134.

Tijani, M. A., Akinleye, M. T. and Jaiyeoba, K. F. (2017). Engineering Properties of Laterites Obtained in Ede, Southwestern Nigeria. International Journal of Engineering and Advanced Technology, 7(1): 160 $-162$. 